\title{
Discursive Analysis of the Written Compositions of STEM Grade-11A Students: A Grounded Theory
}

\section{Erwin L. Purcia}

Master Teacher-II/Senior High School Department Head, Calbayog City National High School, Calbayog City, Samar, Philippines

\section{Abstract}

The written corpora by the STEM Grade-11A students of Calbayog City National High School for the school year 2017-2018 were identified, categorized and analyzed to know the common discursive errors they committed. Initially bounded from Ferris (2005) error analysis model, the researcher analyzed the most recurrent errors that students committed in succeeding writing activities that lasted until the end of the

Corresponding Author: Erwin L. Purcia erwinpurcia@yahoo.com

Received: 23 April 2018 Accepted: 8 May 2018 Published: 4 June 2018

Publishing services provided by Knowledge E

(c) Erwin L. Purcia. This article is distributed under the terms of the Creative Commons

Attribution License, which permits unrestricted use and redistribution provided that the original author and source are credited.

Selection and Peer-review under the responsibility of the IRCHE 2017 Conference Committee. first semester. The result of which was the basis for the theory evolved. The findings showed that the students commonly committed lexical, mechanical, syntactical and morphological errors since most of their errors revealed exceptionally high values in these categories thus; the researcher concluded that students would likely fail to construct written discourses correctly because of these failures. A theory on analyzing errors among written discourses was evolved in order to help students improve their writing skills and combat chances of committing errors.

Keywords: Discursive Analysis, Corpora, Theory Evolved

\section{Introduction}

\section{"Sbagliando simpara" (We can learn through our errors).}

As it is known, the language learning, like any other learning process, involves making errors. In language teaching and learning, the study of learner's error is a technique for identifying, describing and systematically explaining the errors made by a learner, using any of the principles and procedures provided by linguistics. A person could not automatically gain a grip on said language unless he has made series of trials and errors in his use of English as a second language (Ellis, 1997).

Ultimately, learning English as a L2 (second language) is not an easy task. According to Brown, in order to master the English language, learners have to be adequately 
exposed to all of the four basic skills, namely listening, speaking, reading and writing (now five (5) adding viewing via the implementation of the $\mathrm{K}-12$ basic education program). Language teaching in this country is currently focusing on the teaching and learning of the four language skills. However, the standard of English among Filipino children is on the decline despite learning English for several years. Filipino students are still weak in English, especially in their writing skills. They still seem to commit errors in all aspects of language (Brown, 2000).

In the 2004-2005, 2005-2006 and 2011-2012 National Achievement Test Results, English as one of the major core areas taken in the said examination, revealed the low performance rating of students and pupils both in elementary and secondary levels ranging from 51.33, 47.73 and 51.80, respectively. Such results showed examinees were not able to reach the $75 \%$ performance rate. Further, students ultimately fail in answering questions about identifying errors and vocabulary (Nat-Guidelines, 2013).

In Calbayog City National High School, NAT results for English subjects both for second year and fourth year descend every year. Results punched $78.40 \%$ for $2007-2008$, $75.23 \%$ for $2008-2009$ while $72.16 \%$ for $2009-2010$, respectively.

These factual pieces of information inspire the researcher to find out the different common errors that students commit in constructing their own compositions. This study identified the most recurrent errors that students committed which introduced new perspective of how individuals specifically English language learners could learn the language and that is through knowing and avoiding errors they commit in their written compositions.

\section{Objective of the Study}

This study aimed to determine the most recurrent errors that students committed in their corpora in order to evolve a theory on error analysis.

\section{Materials and Methods}

The researcher utilized discourse analysis and grounded theory as research methods of this study. The researcher intentionally used both qualitative types of research in order to analyze most recurrent errors from students written corpora and at the same time evolve a theory that would help them improve their writing skills. Since the entire population of a whole section of STEM-11A students was involved, total or complete enumeration was utilized by the researcher in identifying the respondents of this study. 


\subsection{On the discourse analysis}

The researcher analyzed the first to the tenth written corpora of the students from STEM-11A section in their $21^{\text {st }}$ Century Literature from the Philippines and the World class. The researcher instructed the students to write compositions that cut across several topics of their choice. At first, Ferris (2005) error analysis model was used by the researcher as aid for the analysis. In the succeeding analysis of the written corpora, the most recurrent errors were extracted as basis for the theory evolved. These written corpora were subjected to thematic analysis. The researcher utilized coding and classified the analyzed errors into either mechanical, syntactical, lexical and morphological. Errors under each category are as follows:

A. Lexical Errors-Word choice, Word form, Informal usage, Idiom error, Pronoun error

B. Mechanical Errors-Punctuation, Spelling and Capitalization

C. Morphological Errors

Verbs: Tense, Form, Subject-verb agreement

Nouns: Articles/determiners, Noun endings (plural/possessive)

D. Syntactic Errors-Sentence structure, Run-ons, Fragments

\section{Results and Discussion}

This study underscored the analysis, categorization and identification of persistent errors that emanate from the written corpora of the students. Accordingly, this highlighted which among the categories do their committed errors fall.

The following tables below present the persistent errors that students had in their written corpora.

Written compositions in terms of lexical errors are composed of five categories namely; word choice, word form, informal usage, idiom error, and pronoun error. The figures opposite each category indicate the average number of times such error is 7.45 committed by the students. The table shows that the students committed very low in word form (1.40), informal usage (1.20), idiom error (0.90) and pronoun error (1.35), but moderately high in word choice (2.60). The cumulative mean of 7.45 indicates that the students committed exceptionally high in terms of lexical errors in their written compositions. 
TABLE 1: Students' Lexical Errors Committed.

Category
Word Choice
Word Form
Informal Usage
Idiom Error
Pronoun Error
Cumulative Mean
standard deviation

\begin{tabular}{|c|}
\hline Weighted Mean \\
\hline 2.6 \\
\hline 1.4 \\
\hline 1.2 \\
\hline 0.9 \\
\hline 1.35 \\
\hline 7.45 \\
\hline 3.49 \\
\hline
\end{tabular}

\begin{tabular}{|c|}
\hline Description \\
Low \\
Very Low \\
Very Low \\
Very Low \\
Very Low \\
\hline Exceptionally High \\
\hline Exceptionally High
\end{tabular}

Table 2 below on the other hand presents the mechanical errors identified, categorized and analyzed by the researcher from the written corpora of the respondents.

TABLE 2: Students' Mechanical Errors Committed.

Category
Punctuation
Capitalization
Spelling
Cumulative Mean
Standard Deviation

\begin{tabular}{|c|}
\hline Weighted Mean \\
\hline 3.35 \\
\hline 2.75 \\
\hline 1.73 \\
\hline 7.83 \\
\hline 3.99 \\
\hline
\end{tabular}

\begin{tabular}{|c|}
\hline Description \\
Exceptionally High \\
Very High \\
Moderately Low \\
Exceptionally High \\
Exceptionally High
\end{tabular}

The table reveals that the students committed errors very high (3.35) in punctuation, high in capitalization and moderately low (1.73) in spelling. The cumulative mean of 7.83 indicates that the students committed exceptionally high in mechanical errors.

Table 5 below presents the morphological errors identified, categorized and analyzed by the researcher from the written corpora of the respondents.

TABle 3: Students' Morphological Errors Committed.

Category
Verbs ( Tenses Form,
Subject-Verb Agreement)
Nouns
(Articles,/Determiners,
Noun Endings,
Plural/Possessive)
Cumulative Mean
standard deviation

\begin{tabular}{|} 
Weighted Mean \\
$\begin{array}{c}3.13 \\
3.78 \\
\\
6.91 \\
3.6\end{array}$
\end{tabular}

\begin{tabular}{|l|}
\hline Interpretation \\
Very High \\
\hline Exceptionally High \\
\hline Exceptionally High \\
\hline Exceptionally High \\
\hline
\end{tabular}


The table shows that the students committed very high (3.13) in terms of verbs. This means that on the average each student committed 3 errors either in tense form or subject-verb agreement. Meanwhile, the students committed very high (3.78) in terms of nouns. This means that each student committed nearly 4 errors either in the use of articles, determiners, noun endings, or plural possessive.

TABLE 4: Students' Syntactical Errors Committed.

Category
Sentence Structure
Run-on
Fragments
Cumulative Mean
Standard Deviation

Weighted Mean

2.3

2.28

1.93

6.51

3.11
Interpretation

Moderately High

Moderately High

Moderately Low

Exceptionally High

Exceptionally High

The table shows that the students committed moderately high (2.30) in sentence structure and run-on (2.28), while moderately low (1.93) in fragments. The cumulative mean of 6.51 indicates that students committed exceptionally high in syntactical errors.

The cumulative mean utilized in identifying the extent of errors committed by the research participants was taken from most recurrent and persistent errors that they had. Intervals of such varied because the highest and lowest number of errors were considered.

\section{Conclusion and Recommendation}

Through the series of writing activities conducted, students had committed recurrent and persistent errors in all categories. However, among these, errors in punctuation and nouns were the most recurrent as they both punched exceptionally high description. Therefore, it is highly recommended that series of activities shall be conceptualized solely intended for mastery of the use of punctuation and noun.

\section{Theory Evolved}

As a result of exhaustive analysis, the researcher came up with the theory "Error Response and Word Interactive Nuncupation (ERWIN) Theory." 
This theory states that students must be engaged in an interactive and communicative learning environment whereby they and the other students should view communication as an important means to understanding. This theory underscores that students must also recognize errors as an important facet in second language learning. And with that, they must be given importance by exposing them to various interactive learning activities that would develop their communicative competence and respond immediately to language errors. In order to do that, providing series of writing activities among them is a necessity to burgeon communicative culture within them and in their schools by and large.

\section{Author's Note}

Dr. Erwin L. Purcia is a Master Teacher-II and Department Head of the Senior High School Department of Calbayog City National High School, Calbayog City, Samar, Philippines. He is a graduate of BSEd-English Cum Laude at Northwest Samar State University, Calbayog City. He finished his Master of Arts in Education major in English at Christ the King College. He took his Doctor of Arts in Language and Literature at the University of Eastern Philippines, Catarman, Northern Samar. He is an Editor of two international journals who has been presenting several research papers from the different parts of the world.

\section{References}

[1] Albaracin, L. G. Some aspects of the interlangugae of selected freshmen high school students: An error analysis. Unpublished master's thesis, University of the Philippines. 1987.

[2] Brown, H. D. (1994). Principles of Language Learning and Teaching. Englewood, New Jersy: Prentince Hall.

[3] Ellis, R. Second language acquisition. Oxford: Oxford University Press. 1997.

[4] Ferris, D.R..Treatment of error in second language writing. Ann Arbor: The University of Michigan Press. 2005.

[5] National Achievement Test Results-DepEd (2013).http://www.depedqc.ph/ announcements/2013-NAT-GUIDELINES). 